\title{
Performance and Emission of a CI Engine Using Antioxidant Treated Biodiesel
}

\author{
H. K. Rashedul, H. H. Masjuki, M. A. Kalam, and A. M. Ashraful
}

\begin{abstract}
Biodiesel has been a promising clean alternative fuel to fossil fuels, which cuts the emissions that are released by fossil fuels, and perhaps reduces the energy crisis induced by the exhaustion of oil resources in the near future. In this study, the effect of antioxidant additive on engine performance and emission characteristics of an engine fueled with palm biodiesel was investigated and compared with conventional diesel fuel. For this study, four fuel samples including pure diesel, diesel-biodiesel (B20), diesel-biodiesel-additive (B20+additive) and pure biodiesel (B100) were used in a multi cylinder, four stroke, water cooled, direct injection diesel engine. Engine tests were performed at various engine speed of $1000 \mathrm{rpm}$ to 4000 rpm with $50 \%$ throttle opening. Engine performance and emission concentrations are investigated by determining the break specific fuel consumption (BSFC), brake thermal efficiency, $\mathrm{CO}, \mathrm{HC}, \mathrm{NO}_{x}$ and smoke opacity using gas analyzers. The results showed that the use of baynox plus solution as additive with palm methylester gave average $3.10 \%$ higher brake power as well as $23.2 \%$ and $2.40 \%$ lower $\mathrm{NO}_{x}$ and brake specific fuel consumption than the biodiesel blend without additives.
\end{abstract}

Index Terms-IC engine, palm methyl ester, additives, $\mathrm{NO}_{x}$.

\section{INTRODUCTION}

The need for energy remains to increase worldwide, creating a need to branch out from conventional fossil fuels [1], [2]. The global energy requirement is anticipated to increase about $30 \%$ in the decades between 2010 and 2030 [3] [4]. Increased environmental concern, tougher vehicle emission norms, increasing prices and uncertainties concerning petroleum availability necessities the search of a viable alternative fuel, which is more environmental friendly [5]-[7]. In recent years, there has been an increased emphasis on extending the role of alternative fuels. Aside from reducing dependency on fossil fuels, a lot of the effort to increase the utilization of alternative fuels has been prompted by the importance of reducing greenhouse gases emissions, such as carbon dioxide, in reaction to the increasing menace of global warming [8]-[10]. Biodiesel is a promising alternative fuel, which is renewable, biodegradable, non-toxic and environmental friendly [4], [11], [12]. It is an ester based oxygenated fuels consisting of a long chain fatty acid and can be derived from vegetable oils (both edible and non-edible), waste cooking, and animal fats oil etc. [13]. Biodiesel in

Manuscript received June 10, 2015; revised December 10, 2015. This work was supported in part by the High Impact Research under Grant UM.C/HIR/MOHE/ENG/60.

The authors are with the Department of Mechanical Engineering, University of Malaya, 50603, Kuala Lumpur, Malaysia (e-mail: mdrashedhasan82@gmail.com, maszuki@um.edu.my, kalam@um.edu.my, alam.ashraful31@gmail.com). particular has been proven to be one of the best alternatives for fossil fuel because it produces less pollutant emissions. Most of the leading countries such as Germany, France and the United States of America have been conducting extensive Biodiesel research. Also, developing countries such as Brazil, Malaysia, India and Indonesia have been conducting similar research [14], [15]. Many authors investigated the performance and emission characteristics of diesel engine using biodiesel and its blends [14]-[19]. Lin and Rong [20] investigated the effect of waste cooking oil biodiesel, fish oil biodiesel and 2D diesel on a 4-cylinder direct injection engine. They observed higher $\mathrm{NO}_{x}$ and PM emissions and lower $\mathrm{CO}$ emission while using fish oil biodiesel than using waste cooking oil biodiesel. However, both biodiesels showed lower PM, $\mathrm{CO}$ emission and higher $\mathrm{NO}_{x}$ emissions compared to diesel fuel. The fish oil biodiesel gave lower BSFC than to the waste cooking oil biodiesel. Behçet [21] carried out an experiment to observe the effect of fish oil biodiesel on a direct injection diesel engine and found lower $\mathrm{CO}$ and $\mathrm{HC}$ emission but higher BSFC and $\mathrm{NO}_{x}$ emission. Lin et al. [22] investigated the effect of vegetable methylester on diesel engine and observed the same brake power and the reduction of all emission except $\mathrm{NO}_{x}$. Buyukkaya [23] used standard diesel fuel, rapeseed biodiesel and blends of B5, B20, B70 on a 6-cylinder, 4-stroke, turbocharged DI diesel engine at full load condition with variable engine speeds. The results indicated a reduction in $\mathrm{CO}$ emissions for biodiesel blends compared to diesel. The use of biodiesel produced lowered smoke opacity (up to 60\%). However there was an increase in $\mathrm{NO}_{\mathrm{X}}$ due to higher combustion temperature. Some researchers have reported that the use of some fuel additives in the biodiesel blend can uplift some key properties of biodiesel and improve the performance and emission parameters [24]-[30]. Kalam and Masjuki [31] investigated the effect of an antioxidant additive named 4-nonyl phenoxy acetic acid ( $1 \% \mathrm{v} / \mathrm{v})$ with palm biodiesel (B20) and found that the additive produce $2.93 \%$ higher brake power and $5.03 \%$ lower brake specific fuel consumption compared to biodiesel blend without additive. They also found that the use of such additive to biodiesel reduces the $\mathrm{NO}_{x}, \mathrm{CO}$ and $\mathrm{HC}$ emissions. Shahabuddin et al. [32] experimented the effect of anti-corrosion additives in a turbocharged indirect injection diesel engine emission while the engine running with palm biodiesel. The authors found fuel B20 with $1 \%$ anti-corrosion additives produced $1.73 \%$ and $9 \%$ higher brake power than pure B20 and ordinary diesel fuel respectively and consumed $6 \%$ and $26 \%$ lower BSFC as compared to ordinary diesel and pure B20. They obtained that the fuel with additive produced lowest level of $\mathrm{CO}, \mathrm{HC}$ and $\mathrm{NO}_{x}$, emission as compared to ordinary diesel. Balaji and Cheralathan [33] investigated the 
effect of cottonseed methyl ester with of antioxidant additives on engine emission and engine performance characteristics and found slight decrease in $\mathrm{BSFC}, \mathrm{NO}_{x}, \mathrm{CO}_{2}, \mathrm{HC}$ and smoke emission and increase in $\mathrm{BTE}$ and $\mathrm{CO}$ emission. However from the above literature it is clearly seen that the use of biodiesel fuel in the diesel engine increases BSFC and $\mathrm{NO}_{x}$ emission. On the other hand, it decreases BTE, and other regulated emissions. In this paper, a new and commercially available fuel additive named baynox plus solution is used with palm biodiesel to investigate and evaluate the engine performance parameters and emission characteristics and also compare all the results with diesel fuel.

\section{Methodology}

A four cylinder indirect injection water cooled diesel engine was applied to the present work. The schematic diagram of the engine test bed is pictured in Fig. 1. The engine was mated to an eddy current dynamometer named Froude Hofman AG 150. The fuel flow rates were measured using a positive displacement flow meter named Kobold ZOD. Engine oil, exhaust gas, cooling water and inlet air temperatures were evaluated utilizing a thermocouple. An exhaust gas analyzer (BOSCH BEA-350) was used to measure the $\mathrm{NO}_{x}, \mathrm{CO}_{2}, \mathrm{CO}$ and $\mathrm{HC}$ emission. A smoke meter called AVL was used for measuring the smoke opacity. The details of the engine test bed are listed in Table I. Experiments were conducted with pure diesel, diesel-biodiesel (B20), diesel-biodiesel-additive (B20+additive) and pure palm biodiesel (B100) blends on a volume basis at different speed. $1 \%$ (v/v) baynox plus solution as additive was added with B20 blend. To carry out the study, the engine was run with $50 \%$ throttle opening at a different speed from $1000 \mathrm{rpm}$ to 4000 $\mathrm{rpm}$. The engine performance parameters, emissions and exhaust gas temperature were measured to evaluate and compute the behavior of diesel engines. The major physico-chemical properties of all fuel samples are stated in Table II and the details of additive are listed in Table III. Every measurement for all the fuel samples was done three times and averages data were taken.

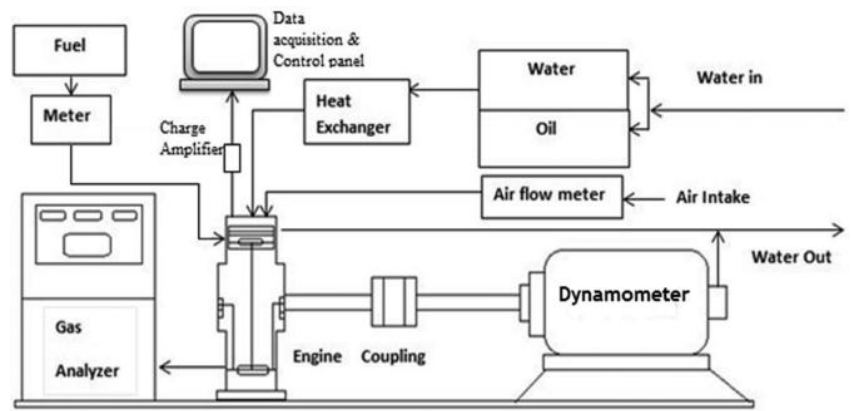

Fig. 1. The schematic diagram of engine test bed.

TABLE I: SPECIFICATION OF THE ENGINE

\begin{tabular}{ll}
\hline Engine type & Water cooled, 4 stroke \\
No. of cylinder & 4 \\
Displacement & $1817 \mathrm{cc}$ \\
Bore & $84 \mathrm{~mm}$ \\
Stroke & $82 \mathrm{~mm}$ \\
Compression ratio & $18.5: 1$ \\
Rated power & $42 \mathrm{~kW} @ 4000 \mathrm{rpm}$ \\
\hline
\end{tabular}

TABLE II: PHYSICO-CHEMICAL PROPERTIES OF USED FuELS

\begin{tabular}{lllll}
\hline Properties & $\begin{array}{l}\text { Diesel } \\
(\mathrm{B} 0)\end{array}$ & B100 & B20 & B20+additive \\
\hline $\begin{array}{l}\text { Calorific value } \\
(\mathrm{Mj} / \mathrm{kg})\end{array}$ & 45.3 & 39.36 & 44.06 & 43.84 \\
$\begin{array}{l}\text { Kinematic viscosity } \\
\text { @ } 40^{\circ} \mathrm{C}(\mathrm{cSt})\end{array}$ & 3.63 & 5.02 & 4.12 & 4.14 \\
$\begin{array}{l}\text { Density @ } 40^{\circ} \mathrm{C} \\
\left(\mathrm{kg} / \mathrm{m}^{3}\right)\end{array}$ & 829 & 879 & 840 & 842 \\
$\begin{array}{l}\text { Flash point }\left({ }^{\circ} \mathrm{C}\right) \\
\text { Oxidation stability (h) }\end{array}$ & 69 & 149 & 80.0 & 83.5 \\
\hline
\end{tabular}

TABLE III: DETAILS OF ADDITIVE

\begin{tabular}{ll}
\hline Product name & Baynox plus solution \\
Type & Antioxidant \\
CAS number & $119-47-1$ \\
Ingredient name & $2,2^{\prime}$-methylenebis (4-methyl-6-tert-butyphenol) \\
Physical state & Liquid \\
Boiling point & $300^{\circ} \mathrm{C}$ \\
Melting point & $-10^{\circ} \mathrm{C}$ \\
Flash point & $\mathrm{Closed} \mathrm{cup:} 180^{\circ} \mathrm{C}$ \\
Density & $0.89 \mathrm{~kg} / \mathrm{L} \mathrm{@} 20^{\circ} \mathrm{C}$ \\
Vapour pressure & $19 \mathrm{hPa} @ 20^{\circ} \mathrm{C}$ \\
Ignition temperature & $255^{\circ} \mathrm{C}$ \\
\hline
\end{tabular}

\section{RESULTS AND DISCUSSIONS}

\section{A. Brake Power}

The variation of brake power against engine speed for all fuel samples are shown in Fig. 2. It is seen that the power values of pure biodiesel and its blend showed a trend of decreasing depending on the content of biodiesel over the entire range of speeds. The characteristics of power values did not vary significantly, according to the type fuel. For D100, B20 and B20+additive blend the maximum power was accomplished at 2500 RPM, however, for B100 and, the maximum power was accomplished at 3500 RPM. D100 gave the maximum brake power of average $11.81 \mathrm{~kW}$, whereas B20, B20+additive blend and B100 gave the brake power of average $11.28 \mathrm{~kW}, 11.63 \mathrm{~kW}$ and $10.47 \mathrm{~kW}$ respectively. From the figure it is also seen that, B20+additive blend gave average $3.10 \%$ higher brake power than B20 blend and $1.52 \%$ lower than diesel fuel and this is because additive blend reduces the viscosity of fuel and increases the combustion quality [34]. B100 blend gave the lowest brake power due to its more viscosity and lower heating value. High viscosity decreases combustion efficiency because of the related bad injection atomization, whereas high lubricity reduces friction loss and improves the brake effective power [35].

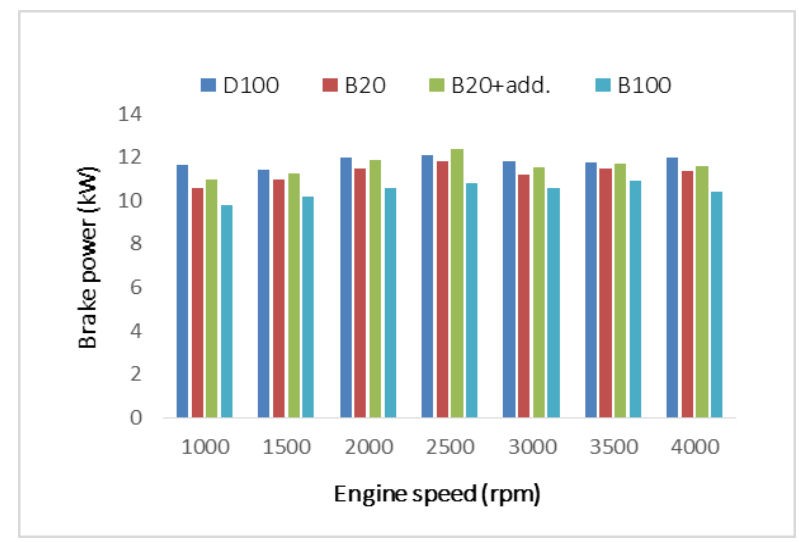

Fig. 2. Variation of brake power with respect to speed. 


\section{B. Brake Specific Fuel Consumption}

Fig. 3 represents the change of brake specific fuel consumption against engine speed for all fuel samples. The BSFC increased as the speed of engine increased. In general, BSFC was found to be more eminent as the dosage rate of biodiesel into the diesel higher; it is because of the lower heating value of biodiesel. Higher density, higher viscosity and lower heating value of fuel produces higher BSFC [34]. BSFC values for all fuel blends showed similar results at lower speed and a very big difference found at medium and higher speed. On average, diesel fuel gave the lowest BSFC values of $407 \mathrm{~g} / \mathrm{kWh}$, whereas B20, B20+additive blend and B100 gave the BSFC values of $492.85 \mathrm{~g} / \mathrm{kWh}, 481 \mathrm{~g} / \mathrm{kWh}$ and $652.85 \mathrm{~g} / \mathrm{kWh}$ respectively. Average rates of decreases in specific fuel consumption on were $2.40 \%$ with B20+additive blend compared to B20 blend and Average rates of increase in specific fuel consumption on were $18.18 \%$ B20+additive blend compared to diesel fuel due to additive higher the lower heating value of biodiesel. It was also observed that neat biodiesel shows the highest BSFC due to its lower heating value.

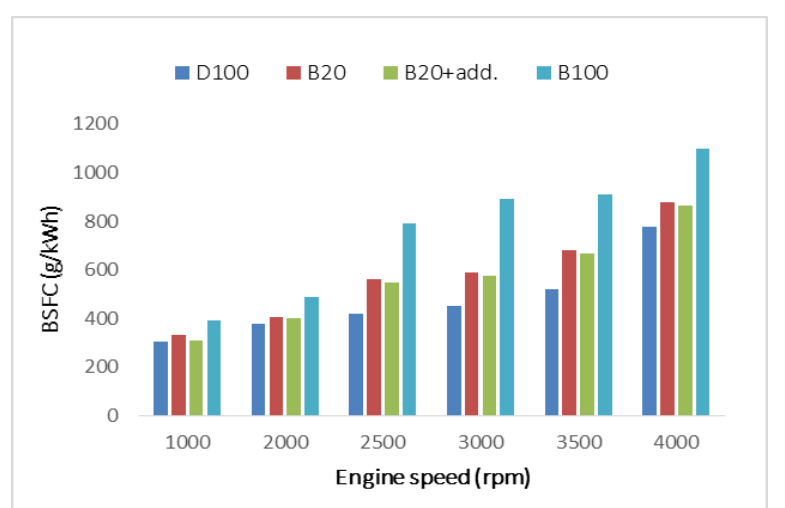

Fig. 3. Variation of brake specific fuel consumption with respect to speed.

\section{C. $N O_{x}$ Emission}

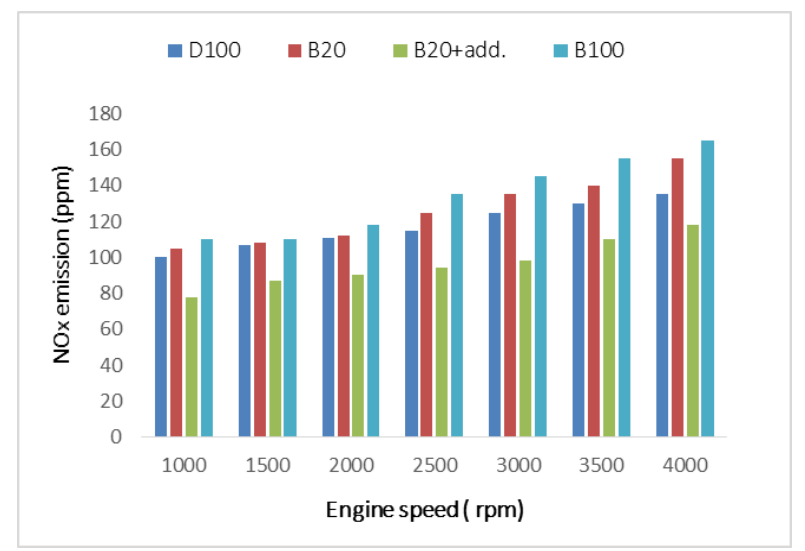

Fig. 4. Variation of $\mathrm{NO}_{x}$ emission with respect to speed.

Fig. 4 represents the variations of $\mathrm{NO}_{x}$ emission values against engine speed for all fuel samples. In general, $\mathrm{NO}_{x}$ emission of biodiesel fuels is higher than diesel fuel. From the figure, it is clearly seen that the $\mathrm{NO}_{x}$ emission tend to higher as the proportion of the biodiesel in blend higher. The explanation behind the increment of $\mathrm{NO}_{x}$ emissions with biodiesel is the higher oxygen $(\mathrm{O})$ content of biodiesel which gives better ignition, and as a result, the combustion temperature increments. $\mathrm{NO}_{x}$ emission is directly related with combustion temperature, thus $\mathrm{NO}_{x}$ emission is increased [35]-[37]. From the figure, it is found that the average $\mathrm{NO}_{x}$ emission diesel fuel, B20, B20+additive blend and B100 were 117.6 ppm, 125.7 ppm, 96.5 ppm and 134 ppm respectively. B20+additive blend showed the best result on $\mathrm{NO}_{x}$ emission among all blends throughout the entire range of speed and it gave the average $17.8 \%, 23.2 \%$ and $28 \%$ reduction of $\mathrm{NO}_{x}$ emission compared to diesel fuel, B20 and B100 blends. This is because of additives in the biodiesel fuel reduce the combustion temperature.

\section{CO Emission}

Fig. 5 demonstrates the carbon monoxide (CO) emissions against engine speed for all fuel samples. The $\mathrm{CO}$ emission of biodiesel fuel is normally lower than diesel fuel. As seen from the figure that, there is a practically direct relations with engine speed, when the engine speed is increased, there is a lessening on the $\mathrm{CO}$ emissions. The greatest $\mathrm{CO}$ emanations are seen with diesel fuel and an increment of the biodiesel degree on the fuel mixture comes about an abatement on the $\mathrm{CO}$ emission due to higher oxygen substance of biodiesel. It is also seen that the average decrease of $\mathrm{CO}$ emission values were $14.2 \%$ with B20, $10.35 \%$ with B20+additive and $23.6 \%$ with B100 compared to diesel. This is occurred due to the properties of blend fuels such as higher oxygen content and low sulphur content. The addition of antioxidant to B20 enhanced the $\mathrm{CO}$ emission by $4.5 \%$ compared to pure $\mathrm{B} 20$ due to reduction of free radical formation by antioxidants [38].

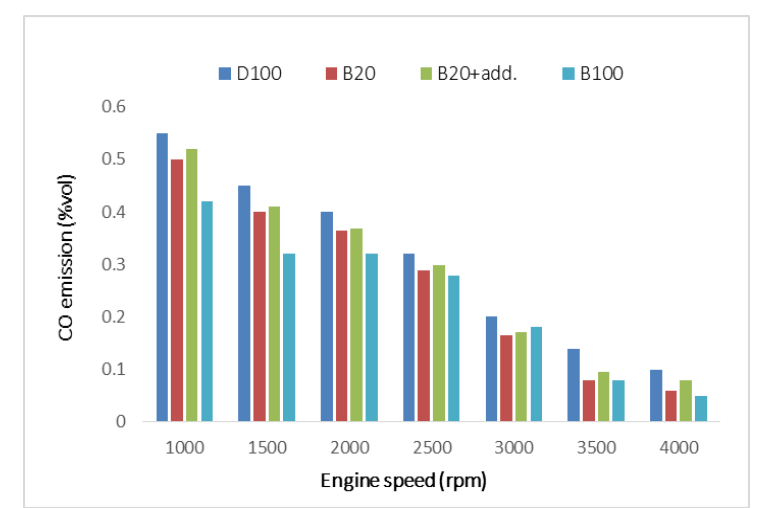

Fig. 5. Variation of $\mathrm{CO}$ emission with respect to speed.

\section{E. HC Emission}

For a complete combustion an intimate air fuel mixing should take place but if the mixture is too lean due to excess air that may cause an inhomogeneous air fuel mixture in the cylinder resulting in poor combustion, and hence the amount of hydrocarbon increases. Also, the higher oxygen content in the biodiesel improves the oxidation on unburned hydrocarbons [39]. Fig. 6 demonstrates hydrocarbon emission at different engine speed for various fuels. It is seen that, $\mathrm{HC}$ emission increases with increasing the engine speed Over the whole speed reach, biodiesel fuel demonstrated the noteworthy decrease in $\mathrm{HC}$ emission contrasted with diesel fuel. The average $\mathrm{HC}$ emission for diesel, B20, B20+additive and B100 was found $37.29 \mathrm{ppm}, 31.15 \mathrm{ppm}, 32.8 \mathrm{ppm}$ and 
$29.29 \mathrm{ppm}$ respectively. The addition of antioxidant to B20 enhanced the $\mathrm{HC}$ emission by $5.3 \%$ compared to pure B20 due to reduction of free radical formation by antioxidants [38].

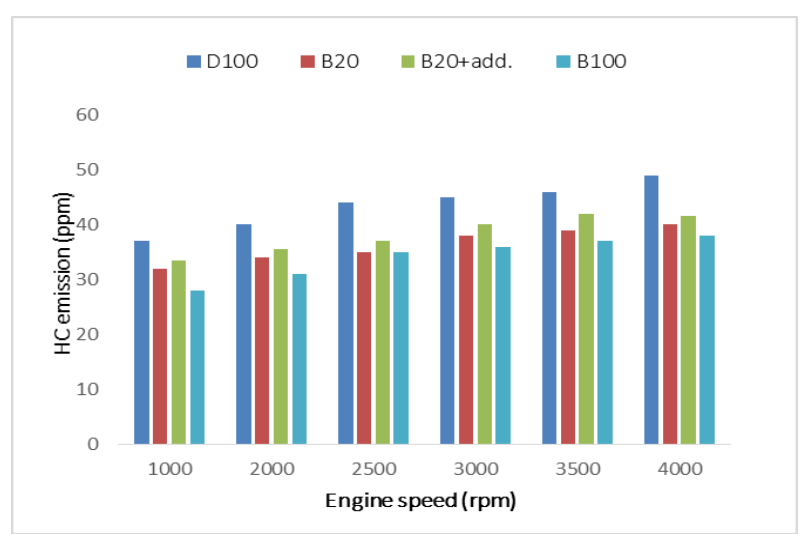

Fig. 6. Variation of $\mathrm{HC}$ emission with respect to speed.

\section{CONCLUSION}

The aim of this work was to explore impact of added additives with palm methyl ester on engine performance and exhaust emission. In light of the trial results the accompanying conclusion can be made:

- Antioxidant enhance the oxidation stability of palm biodiesel.

- Palm biodiesel fuel blends gave slightly lower brake power than diesel. However, B20+additive blend is improved the brake power by $3.10 \%$ compared to B20 blend.

- Brake specific fuel consumption was found higher with palm biodiesel blends. Additive with biodiesel (B20) blend is reduced BSFC by $2.4 \%$ compared to $\mathrm{B} 20$ blend.

- $\mathrm{NO}_{x}$ emission of palm biodiesel is higher than diesel. B20+additive blend is reduced the $\mathrm{NO}_{x}$ emission by $23.2 \%$ than B20 blend.

- Palm biodiesel usually reduces the $\mathrm{CO}$ and $\mathrm{HC}$ emissions compared to diesel fuel. $\mathrm{CO}$ and $\mathrm{HC}$ emissions are decreased by $18.7 \%$ and $29.5 \%$ compared to diesel respectively with the addition of additives to biodiesel (B20) blend.

Finally, Baynox plus solution is compelling for biodiesel and is suitable to be utilized as a part of diesel engine. More researches can be conducted by changing the feedstocks of biodiesel and the dose rate of additive to the blend.

\section{ACKNOWLEDGMENT}

The authors would like to appreciate University of Malaya for financial support through High Impact Research grant titled: Development of Alternative and Renewable Energy Career (DAREC) having grant number UM.C/HIR/MOHE/ENG/60.

\section{REFERENCES}

[1] O. Özener, L. Yüksek, A. T. Ergenç, and M. Özkan, "Effects of soybean biodiesel on a DI diesel engine performance, emission and combustion characteristics," Fuel, vol. 115, pp. 875-883, 2014.

[2] S. K. Hoekman, A. Broch, C. Robbins, E. Ceniceros, and M. Natarajan, "Review of biodiesel composition, properties, and specifications,"
Renewable and Sustainable Energy Reviews, vol. 16, no. 1, pp. 143-169, 2012.

[3] A. E. Atabani, A. S. Silitonga, I. A. Badruddin, T. M. I. Mahlia, H. H. Masjuki, and S. Mekhilef, "A comprehensive review on biodiesel as an alternative energy resource and its characteristics," Renewable and Sustainable Energy Reviews, vol. 16, no. 4, pp. 2070-2093, 2012.

[4] H. K. Rashedul, H. H. Masjuki, M. A. Kalam, A. M. Ashraful, S. A. Rahman, and S. A. Shahir, "The effect of additives on properties, performance and emission of biodiesel fuelled compression ignition engine," Energy Conversion and Management, vol. 88, pp. 348-364, 2014.

[5] M. Mofijur, H. H. Masjuki, M. A. Kalam, and A. E. Atabani, "Evaluation of biodiesel blending, engine performance and emissions characteristics of Jatropha curcas methyl ester: Malaysian perspective," Energy, vol. 55, pp. 879-887, 2013.

[6] E. Lai, "Biodiesel: Environmental friendly alternative to petro diesel," J. Pet Environ Biotechnol., vol. 5, p. e122, 2014.

[7] S. Chattopadhyay and R. Sen, "Fuel properties, engine performance and environmental benefits of biodiesel produced by a green process," Applied Energy, vol. 105, pp. 319-326, 2013.

[8] P. Wibul et al., "Life cycle assessment of biodiesel production from microalgae in Thailand: Energy efficiency and global warming impact reduction," Chemical Engineering, vol. 29, 2012.

[9] J. Xue, T. E. Grift, and A. C. Hansen, "Effect of biodiesel on engine performances and emissions," Renewable and Sustainable Energy Reviews, vol. 15, no. 2, pp. 1098-1116, 2011

[10] H. Aydin and C. Ilkilic, "Exhaust emissions of a CI engine operated with biodiesel from rapeseed oil," Energy Sources, Part A: Recovery, Utilization, and Environmental Effects, vol. 33, no. 16, pp. 1523-1531, 2011.

[11] H. Fukuda, A. Kondo, and H. Noda, "Biodiesel fuel production by transesterification of oils," Journal of Bioscience and Bioengineering, vol. 92, no. 5, pp. 405-416, 2001.

[12] A. Demirbas, "Importance of biodiesel as transportation fuel," Energy Policy, vol. 35, no. 9, pp. 4661-4670, 2007.

[13] R. L. McCormick, M. S. Graboski, T. L. Alleman, A. M. Herring, and K. S. Tyson, "Impact of biodiesel source material and chemical structure on emissions of criteria pollutants from a heavy-duty engine," Environmental Science \& Technology, vol. 35, no. 9, pp. 1742-1747, 2001.

[14] N. Kumar and S. R. Chauhan, "Performance and emission characteristics of biodiesel from different origins: A review," Renewable and Sustainable Energy Reviews, vol. 21, pp. 633-658, 2013.

[15] B. S. Chauhan, N. Kumar, and H. M. Cho, "A study on the performance and emission of a diesel engine fueled with Jatropha biodiesel oil and its blends," Energy, vol. 37, no. 1, pp. 616-622, 2012.

[16] L. Zhu, C. S. Cheung, W. G. Zhang, and Z. Huang, "Combustion, performance and emission characteristics of a DI diesel engine fueled with ethanol-biodiesel blends," Fuel, vol. 90, no. 5, pp. 1743-1750, 2011.

[17] B. S. Chauhan, N. Kumar, H. M. Cho, and H. C. Lim, "A study on the performance and emission of a diesel engine fueled with Karanja biodiesel and its blends," Energy, vol. 56, pp. 1-7, 2013.

[18] I. R. Fattah, H. H. Masjuki, M. A. Kalam, M. A. Wakil, H. K. Rashedul, and M. J. Abedin, "Performance and emission characteristics of a CI engine fueled with Cocos nucifera and Jatropha curcas B20 blends accompanying antioxidants," Industrial Crops and Products, vol. 57, pp. 132-140, 2014.

[19] H. K. Rashedul, H. H. Masjuki, M. A. Kalam, A. M. Ashraful, M. M. Rashed, I. Shancita, and T. Shaon, "Performance and emission characteristics of a compression ignition engine running with linseed biodiesel," RSC Advances, vol. 4, no. 110, pp. 64791-64797, 2014.

[20] C. Y. Lin and R. J. Li, "Engine performance and emission characteristics of marine fish-oil biodiesel produced from the discarded parts of marine fish," Fuel Processing Technology, vol. 90, no. 7, pp. 883-888, 2009.

[21] R. Behçet, "Performance and emission study of waste anchovy fish biodiesel in a diesel engine," Fuel Processing Technology, vol. 92, no. 6, pp. 1187-1194, 2011.

[22] B. F. Lin, J. H. Huang, and D. Y. Huang, "Experimental study of the effects of vegetable oil methyl ester on DI diesel engine performance characteristics and pollutant emissions," Fuel, vol. 88, no. 9, pp. 1779-1785, 2009.

[23] E. Buyukkaya, "Effects of biodiesel on a DI diesel engine performance, emission and combustion characteristics," Fuel, vol. 89, no. 10, pp. 3099-3105, 2010. 
[24] D. Nagdeote and M. Deshmukh, "Experimental study of diethyl ether and ethanol additives with biodiesel-diesel blended fuel engine," Int $J$ Emerg Technol Adv Eng, vol. 2, pp. 195-199, 2012.

[25] K. Varatharajan and M. Cheralathan, "Effect of aromatic amine antioxidants on $\mathrm{NO}_{x}$ emissions from a soybean biodiesel powered DI diesel engine," Fuel Processing Technology, vol. 106, pp. 526-532, 2013.

[26] O. M. Ali, R. Mamat, and C. K. M. Faizal, "Review of the effects of additives on biodiesel properties, performance, and emission features," Journal of Renewable and Sustainable Energy, vol. 5, no. 1, 2013.

[27] S. Sivalakshmi and T. Balusamy, "Effect of biodiesel and its blends with oxygenated additives on performance and emissions from a diesel engine," Journal of Scientific and Industrial Research, vol. 70, pp. 879-883, 2011.

[28] N. Vedaraman, S. Puhan, G. Nagarajan, and K. C. Velappan, "Preparation of palm oil biodiesel and effect of various additives on $\mathrm{NO}_{x}$ emission reduction in B20: An experimental study," International Journal of Green Energy, vol. 8, no. 3, pp. 383-397, 2011.

[29] A. M. Ashraful, H. H. Masjuki, M. A. Kalam, H. K. Rashedul, H. Sajjad, and M. J. Abedin, "Influence of anti-corrosion additive on the performance, emission and engine component wear characteristics of an IDI diesel engine fueled with palm biodiesel," Energy Conversion and Management, vol. 87, pp. 48-57, 2014.

[30] M. M. Rashed, M. A. Kalam, H. H. Masjuki, H. K. Rashedul, A. M. Ashraful, I. Shancita, and A. M. Ruhul, "Stability of biodiesel, its improvement and the effect of antioxidant treated blends on engine performance and emission," RSC Advances, vol. 5, no. 46, pp. 36240-36261, 2015.

[31] M. A. Kalam and H. H. Masjuki, "Testing palm biodiesel and NPAA additives to control $\mathrm{NO}_{x}$ and $\mathrm{CO}$ while improving efficiency in diesel engines," Biomass and Bioenergy, vol. 32, no. 12, pp. 1116-1122, 2008.

[32] M. Shahabuddin, H. H. Masjuki, M. A. Kalam, M. Mofijur, M. A. Hazrat, and A. M. Liaquat, "Effect of additive on performance of CI engine fuelled with bio diesel," Energy Procedia, vol. 14, pp. 1624-1629, 2012.

[33] G. Balaji and M. Cheralathan, "Experimental investigation to reduce emissions of CI (compression ignition) engine fuelled with methyl ester of cottonseed oil using antioxidant," International Journal of Ambient Energy, pp. 1-7, 2013.

[34] B. Q. He, S. J. Shuai, J. X. Wang, and H. He, "The effect of ethanol blended diesel fuels on emissions from a diesel engine," Atmospheric Environment, vol. 37, no. 35, pp. 4965-4971, 2003.

[35] S. Imtenan, H. H. Masjuki, M. Varman, M. A. Kalam, M. I. Arbab, H. Sajjad, and S. A. Rahman, "Impact of oxygenated additives to palm and jatropha biodiesel blends in the context of performance and emissions characteristics of a light-duty diesel engine," Energy Conversion and Management, vol. 83, pp. 149-158, 2014.

[36] L. F. Ramírez-Verduzco, J. E. Rodríguez-Rodríguez, and A. del Rayo Jaramillo-Jacob, "Predicting cetane number, kinematic viscosity, density and higher heating value of biodiesel from its fatty acid methyl ester composition," Fuel, vol. 91, no. 1, pp. 102-111, 2012.
[37] J. P. Szybist, J. Song, M. Alam, and A. L. Boehman, "Biodiesel combustion, emissions and emission control," Fuel Processing Technology, vol. 88, no. 7, pp. 679-691, 2007.

[38] I. R. Fattah, H. H. Masjuki, M. A. Kalam, M. Mofijur, and M. J. Abedin, "Effect of antioxidant on the performance and emission characteristics of a diesel engine fueled with palm biodiesel blends," Energy Conversion and Management, vol. 79, pp. 265-272, 2014.

[39] M. M. Alawi, "Performance and emissions of a DI diesel engine fueled by different biodiesel blends," Ph.D. dissertation, 2014.

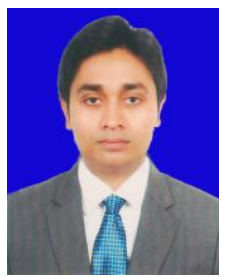

H. K. Rashedul was born on July 1, 1987. He is a mechanical engineer and received his B.Sc. degree in engineering in 2012 from Dhaka University of Engineering and Technology, Bangladesh. $\mathrm{He}$ is perusing his master's degree in the field of energy engineering from University Malaya, Malaysia. He is doing his final project in the felid of IC engine with biodiesel for fulfillment of master's degree.

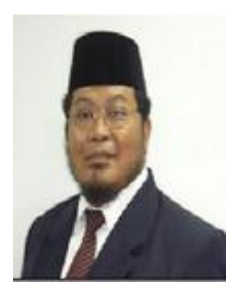

H. H. Masjuki obtained his B.Sc. of mechanical engineering degree, from Leeds University, U.K. in 1977. He continued to pursue his M.Sc. degree in tribology and Ph.D. degree from the same university and graduated in 1978 and 1982 respectively. Upon the completion of his studies, he was being appointed as a lecturer in 1983 at University of Malaya. He is currently appointed as a professor at the Mechanical Engineering Department, University of Malaya. He has published many ISI journals and his H-index is 10

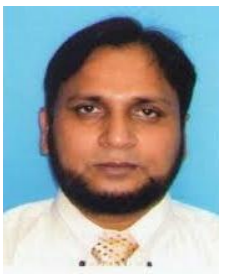

M. A. Kalam is working as a senior lecturer in the Department of Mechanical Engineering, University of Malaya (UM), Malaysia. He has obtained the undergraduate degree from KUET, Bangladesh, master and $\mathrm{PhD}$ degrees from $\mathrm{UM}$. His research areas are broad like fuel combustion, bio lubricant and biofuels testing in IC engines. He has published many ISI journals and his H-index is 21.

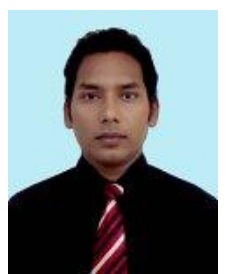

A. M. Ashraful completed his B.Sc. degree in engineering degree from Dhaka University of Engineering and Technology, Bangladesh. He is now perusing his M.Sc. degree in engineering in University of Malaya, Malaysia. He has published more than 10 ISI papers. 